\title{
Separation and Determination of Trace Elements in Metals
}

Atsushi MizuIKE

\section{1.はじめに}

正業材料という見地から，また基礎科学研究に㧈い て，金属中の極微量成分元素の種類や含有率が固体物性 に及ほす影響について，大きな関心が持たれるように なってすでに久しいが，科学技術のますますの高度化に 伴ってその重要性はさらに増大しつつある。この分野で は物理的な物性の測定とともに化学組成の分析が必要不 可欠である.

かつては $10 \mu \mathrm{g} / \mathrm{g}(\mathrm{ppm})$ レベルですら閒題にされて いなかったのに，現在では ng/g (米 part per billion, ppb, 英 part per milliard, ppM) レベル，場今によって はそれ以下のものの䇥量が要求されるようになった。 のような極微量成分元素を正確に定量することは，特に 好都合な場合を除き，決して簡単ではない，物理的測定 に此べると，一般に化学分析はさらに複雑で難しい問題 を含んでいるので, 満足できる尘量下限, 精度, 正確さ をうることはなかなか突易ではない。

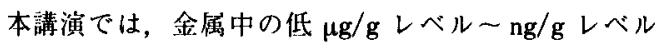
の極微量成分元素の分離と定量の現状，考え方，問題点 将来の展望などを, 私どもの研究を例に挙げつつ, 分析 化学の専門外の方々にもご理解いただけるようにお話し 申し上げたい。

\section{2. 直接定量か分離定量か}

金属中の極微量成分元素の管量には大別して二つのや り方がある.その一つは逍接定量であってマトリックス, すなわち主成分の共存のままで分析を行うものであり， 他の一つは定量に先立って目的極微量成分元素をマト リックスからあらかじめ分離濃縮するものである。

\section{$2 \cdot 1$ 直接定且}

直接定量をさらに三つに分類することができる。

(1)試料そのままの形で分析を行い，しかも分析後に 試料がもとのままの形で残るもので，一般に非破壊分析 といわれる、たとえば蛍光 X 線分析では，試料にX 線 を照射し，試料中の目的極微量成分元素から発生する特 性 X 線 (蛍光 X 線)を測定するので，分析後でも試料は なんら变化していない。また中性子放射化一 $\gamma$ 線スペク トロメトリーは, 試料を原子炉の中に挿入し, 試料中の 目的極微量成分元素の一部を熱中性子による原子核 闰忍によって放射性核種に変換し，これから放射される $\gamma$ 線を測定するものであって，短時問の中性子照射の場 合には，適当時間放置後に放射能は完全になくなり，ま た核反忍によるその他の变化も全く無視できる程度であ る.

(2)試料そのままの形で分析を行うが，分析の際試料 が損傷する場合であって，たとえばスパーク放電やアー ク放電を用いる発光分光分析，スパーク放電やイオン衝 撃によって試料から放出される極微量成分元素のイオン を測定するスパークソース質量分析や二次イオン質量分 析がこれに当たる。

(3)試料を酸などによって完全に分解して溶液とした のち，誘導結合高周波プラズマ (Inductively Coupled Plasma, ICP) 発光分光分析, 原子吸光分析のようなお 法でこの中の目的極微量成分元素を定量するものであ る. 試料の分解に融解法を用い生成した固体を分析する 方法もある。

以上三つのうち分析方法としては(1)がもっとも理 想的なものであり，( 3 )がもっとも少るものであること はいうまでもない。一般にいずれの直接定量法も，後述

平成 2 年 9 月本会講演大会における浅田賞受賞記念特別講演 平成 2 年 10 月 22 日受付 (Received Oct. 22, 1990)

* 東京理科大学工学部教授 - 名古屋大学名誉教授 工博 (Professor, Faculty of Engineering, Science University of Tokyo, Professor Emeritus, Nagoya University, 1-3 Kagurazaka Shinjuku-ku, Tokyo 162)

Key words : metals ; high-purity metals; trace elements ; impurities; instrumental determination ; preconcentration; separation. 
する分離定量法に比べて，操作が籣単辻速である点です ぐれている。しかし極微量成分元素がマトリックスに よって希积されているため，尘塦下限をあまり下げるこ とはできない。ささらに直接运量法はいずれもマトリック スの影響を非常に受ける。たとえば発光分光分析，啠望 分析など各種のスペクトロメトリーにおいて，マトリッ クスの強いスペクトル線が弱骑い極微量成分元素の線に重 複するといった単純な妨砧から，機構がいまだ十分に明 らかにされていないような複雑なものまで，マトリック

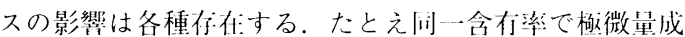
分元素が份在していてもマトリックスが異なれば信罗強 度は一般に異なるので，足量にあたっては朴知試料とほ とんど闹じ組成の既知組成の標準試料を必要とする。低 $\mu \mathrm{g} / \mathrm{g}$ レベル以下の領域で信頼度の高い標準試料を入手 することはしばしばきわめて网難である。

このような理山で，计接分星法は一般に，尘量下限， 尘量值の精度，正確さなどの帒で十分に満足できるもの ではない。

\section{$2 \cdot 2$ 分離定量}

マトリックスを定量に先立って分離除上し, 目的極微 量成分元素を濃縮することによって，上記の問題を解決 することができる。このオ法によれば，理論的には，武 料採取量を増大させることによって無限に低含们摔の概 微量成分元素の分量ができるはずである。しかし实際に は次のような諸原团によって，ある程度以下の定星下限 はえられない。

（1）マトリックスから分離濃縮するときに目的妳微量 成分元素の損众が起こる. 分離方法には理淪的にも回収 淬を $100 \%$ にできないものがある。また分離を行うに当 たって使用する無器壁への吸着, 陚料分解時の蒸発, 不 適当な操作などによっても損火が起こる，超低濃度溶液

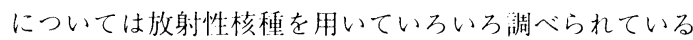
が，各種の買常挙動が見られ，いまだ十分明らかでない 点が多い，損尒の伦険性は極微量成分元素の含竹摔が低 くなればなるほど大きくなる。

( 2 ) 实験公のふん讲気中の蒸父，エーロゾル，ほこり， 分離濃縮に使用する高純度試薬中の晸微童不純物, 茯器

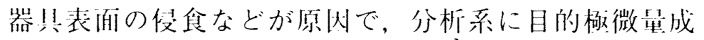
分元素と间じ元素が混人して正の识差が生ずる。この ほか目的極微量元素を吸着する微粒子や定量を妨垈す る他物質が外部から混人し，伿または正の呮差を生ず ることもある。このような現象はコンタミネーション (Contamination) と呼ばれ, 極微量成分元素の含枋淬が 低くなるほどその影算は大きくなる。

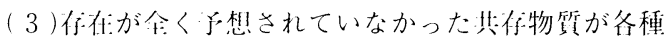
の十涉をする。一般に目的标微量元素の含有淬が低くな るほど，十涉する其你物椞の種颣が増加する叮能性があ る。

(4)試料採取量の增大に伴い，武料の分解や分離濃䋠
に要する時閂や労力が增し，操作が林難になる。

以上の上うな諸問题があるにもかかわらず，極微量成

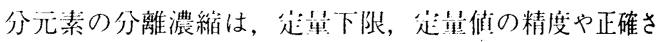
の问上にきわめて存効である。したがって現在 $\mathrm{ng} / \mathrm{g}$ レ ベル以下の杫微量成分元秦の仚量の主流はこのやり方で ある。特に標準陚料の保䃌储の做付けに不叮欠の手段で ある。

\section{3. 極微量成分元素の定量の諸方法}

Fig. 1 に现在:よく使われている齐種のう法の足量下限

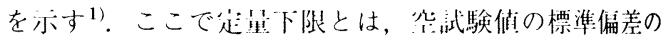

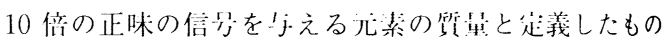

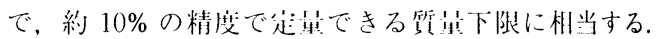
润中線の太さは，それぞれの分量下限を持つ元素の数に 比例して描いてある。こ机は 1982 年, 当時私も正委員

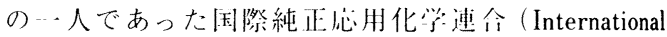
Union of Pure and Applied Chemistry, IUPAC) の微量 分析扰よびトレースアナリシス委只会でとりまとめた デー夕に基づいて作製したものであるが，间‥元素に ついても装置，試㩰，齐種尖験条作によってプラス。 マイナス 1 けた以上も変わるので，およその目安を与 えるものとご承知いただきたい，分埋卜限は一般にピ コグラム $(\mathrm{pg})$ レベル，特殊な場介でもフェムトグラム $\left(\mathrm{fg}, 10^{-15} \mathrm{~g}\right)$ レベル忙まりである。ここにホすすす法の

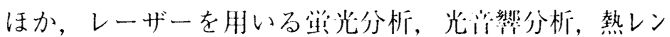
ズ吸光分析，イオン化分析や ICP 翼虽分析など新しい 分析技術もいろいろ開発されているが，尖望下限をこれ 以下にすることは難しい．

現在の測分技術では，光子や電子やイオンの 1 做 1 個 を計数することができるので，计数效济，雑话，バック グラウンド計数，統汁的ゆらぎなどを教虫しても、これ

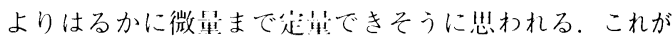

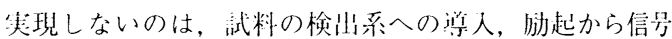
の検出に羊るすべての過程に扰いて效濰が现在非常に低 いからである。もちろん特殊な場仝には，たとえば透過

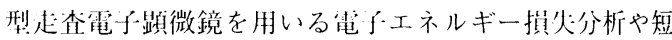
半隇期放射性核種の放射能测分によって，数十一数百做 の原子 $\left(10^{-20} \sim 10^{19} \mathrm{~g}\right)$ を娭壮することも不川能では ない。

金属中の極微量成分元素の足星に適しだ法として， 私どもの研究しだののものについて䢞べよう。

\section{$3 \cdot 1$ ストリッピングボルタンメトリー}

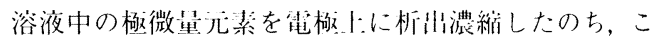

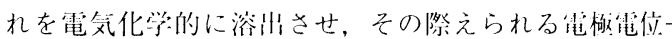
電流曲線（ストリッピング曲線）を利朋するお洪であ る、金属を酸などに溶解したのち，ただちに適用でき，

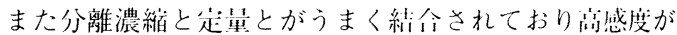
えられるので，私どもは1960 尔:代半ばごろからこの研 究を開始した。 
Molecular absorption spectrophotometry Atomic absorption spectrometry Flame Atomic absorption spectrometry Electrothermal Atomic fluorescence spectrometry Emission spectrography $\mathrm{DC}$ arc

Emission spectrography Copper spark)

Emission spectrography (Graphite spark) Emission spectrometry $\backslash$ ICP Emission spectrometry Flame) $\mathrm{X}$-ray fluorescence spectrometry Spark-source mass spectrometry

Neutron activation analysis Non-destructive) Neutron activation analysis Chemical separation Polarography (DC)

Polarography Linear sweep \& Cathode ray Polarography Pulse

Stripping voltammetry

Ion-selective electrode potentiometry
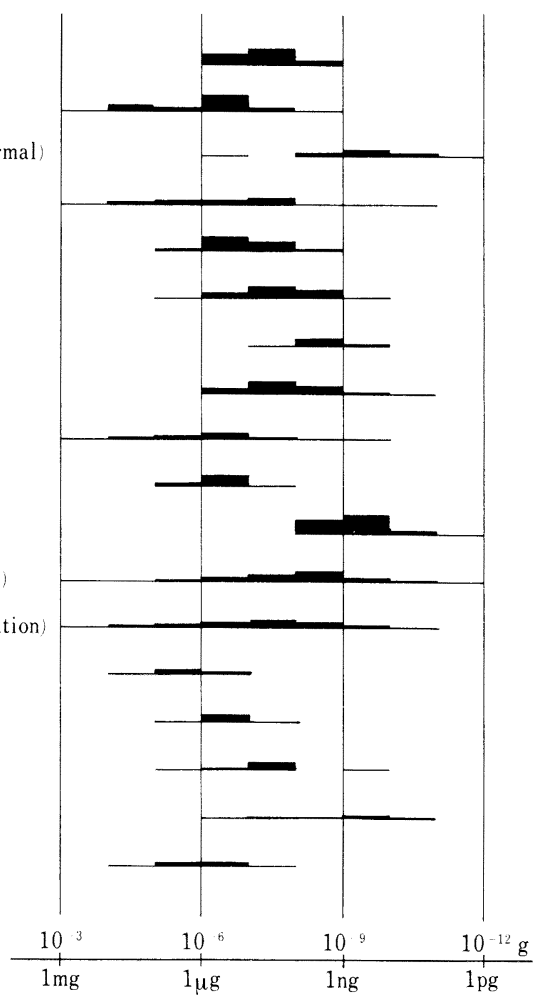

Fig. 1. Limits of determination ${ }^{1)}$.

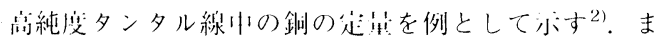
ずFig. $2 \mathrm{~A}$ のようにして，5M ふっ化水尖酸-1 M 硄 酸-1.75 × $10^{4} \mathrm{M}$ 水銀（II）を晸解液, 武料夕ンタル

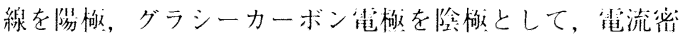

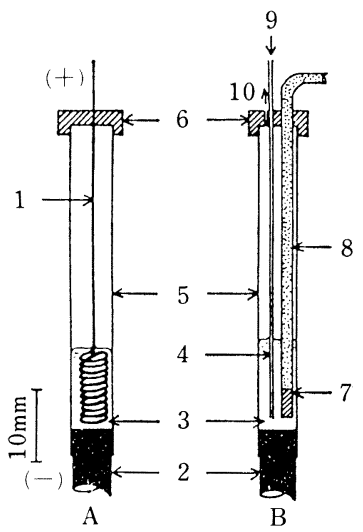

A : Anodic dissolution of sample $B$ : Stripping voltammetry

1: Tantalum wire sample 2: (ilassy carbon electrode

3:200- $\mu$ l electrolyte 4: Platinum tube electrode 5: Teflon

tubing 6: Teflon lid 7 : Sintered polyethylene $8:$ Salt bridge

9 : Nitrogen gas inlet 10: Nitrogen gas outlet

Fig. 2. Microelectrolysis cell ${ }^{2)}$.
度約 $8 \mathrm{~mA} / \mathrm{cm}^{2}$ で 5 10 min 尖電流電解し, 約 3 6 $\mathrm{mg}$ のタンタルを浴解した。つぎにFig. 2 B のように隰極 を白金に取り等え，電解液中の釦の $95 \%$ 以上を水銀と ともに $-0.7 \mathrm{~V}$ (対飽和カロメル電極)に保ったグラ シーカーボン電构上に $10 \mathrm{~min}$ かけて電着させた。この 際マトリックスのタンタルは電解液中に残留する。つぎ にグラシーカーボン電槧の電位を正の方们に $20 \mathrm{mV} / \mathrm{s}$ の速度で走烃し，銅を浴出させ，Fig. 3 に示すような微 分パルス・ストリッピング曲線を記録した。 ピーク高さ

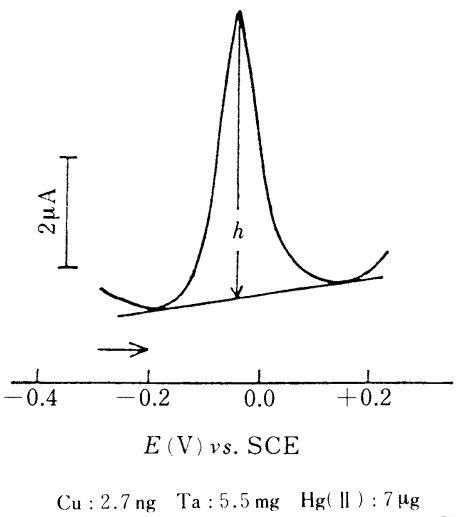

Fig. 3. Stripping curve of copper ${ }^{2)}$. 
$h$ は銅の量に比例した。この方法によってタンタル線中 の $0.3 \sim 0.5 \mu \mathrm{g} / \mathrm{g}$ の銅が相対標準偏差数 \%で $1 \mathrm{~h}$ 以内 で定量できた，分析のはじめから終わりまで単一谷器を 使用するので, 操作が簡単で, 損灯やコンタミネーショ ンのおそれが少ない。またきわめて少量の電解液を用い るので, 短時開でほぼ完全に銅を析出させることができ， 高感度と高精度をうることができる。

適当な電解液と電極を用いることによって，この方法 は各種金属中の極微量成分元素の徙量に伈用することが できた。

\section{$3 \cdot 2$ ICP 発光分光分析}

発光分光分析法は高感度で多元素同時定量に適した力 法であるので，占くから極微量元素の検出，定量に用い られてきた。この方法では，試料の蒸発気化，原子状態 への解離挹よび原子の励起の三つの作用をする光源がき わめて人切であり，感度，精度，ダイナミックレンジな どがこれによって支配される．ICP は Fig. 4 に示すよ うな石英ガラス製 3 重管構造を持つトーチと呼ばれる放 電管の上部外側に高㓮波 $(6 \sim 50 \mathrm{MHz})$ 唀導コイルを置 き，生ずるアルゴンプラズマで，試料（ふつう溶液）を この中に導人して発光させるものであって，比較的最近 開発されたすぐれた光源である。私どもも1970 年代半 ばにこの研究を開始し, 各種装䁇を試作し,プラズマ中 の温度分布やスペクトル線の発光强度分伂，スペクトル 線幅，プラズマのインピーダンスなどを測定し，其存物 質や齐種实験条件などの影響を詳細に研究した。これら

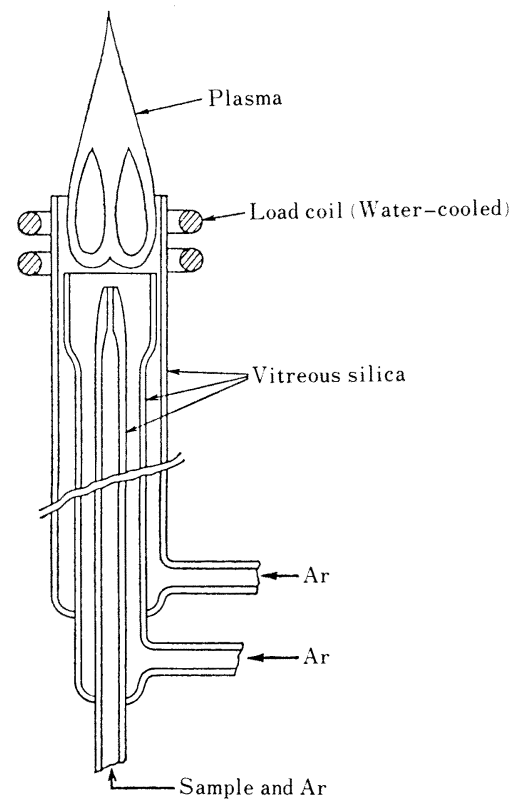

Fig. 4. Inductively coupled plasma torch (conventional).
の成果はプラズマの操作条件の最適化に重要な指針を与 えるとともに，ICP の励起機構や其作物啠の十渉機構 の解明に役立つものである。この他プラズマ中へ効果的 に試料を導入する方法についても多くの研究を行った。

ICPではふつうアルゴンを 15 20 l/min も消費する ので, 私どもは Fig. 5 に亦すような水泠卜ーチを開発 して，性能を低下させることなくアルゴン消蛽量を従来 の 3 分の 1 以下にすることに成功した ${ }^{3 / 4)}$.

多元素京時定荲に用いる分光器としては，ふっう多数 のスリットと検出器をスペクトルの焦南而に並べて，そ れぞれ特定のスペクトル線だけを検川するようにしたポ リクロメーター (Polychromator) が用いられるが,こ れは高価である。私どもは润修波プラズマがきわめて安 定な光源であることに符目して，Fig. 6 にホすすようなコ ンピューター制御モノクロメーターを槛ではじめて試 作しで）これを用いて迅速な多元素逐次定量を行った。 この装萱はモノクロメータ一内に抑人された们英振動极 による波长変淍とこの振動に间期した高速デー夕取得を 利用したもので，安価なばかりでなく、スペクトルプロ ファイルが正確に測定され，妙跍スペクトル線の十渉の 補正抢よびバックグラウンドの補正が川能であるという 特長を持つ。このような考えうに基づくシステムはその

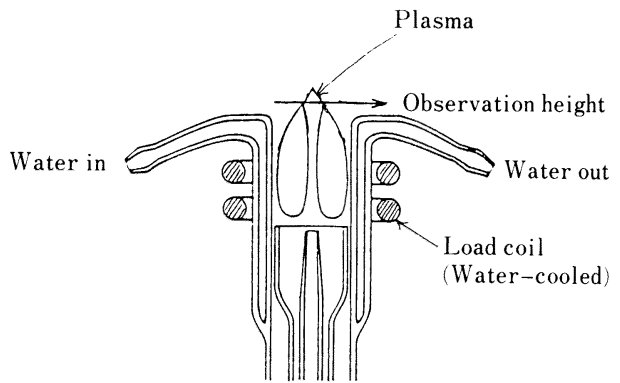

Fig. 5. Inductively coupled plasma torch (water-cooled).

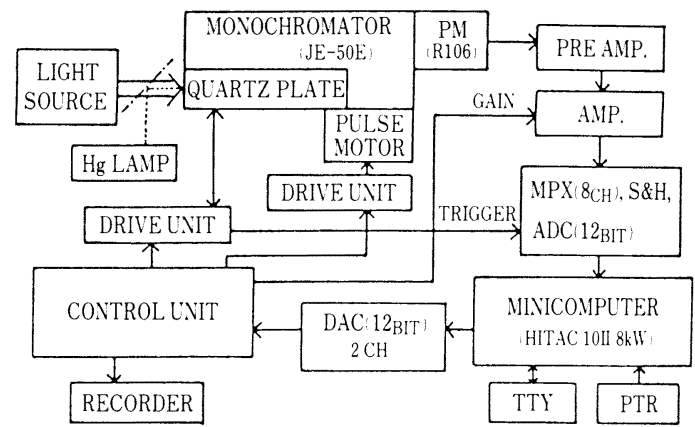

Fig. 6. Block diagram for computer-controlled programmable monochromator ${ }^{5)}$. 


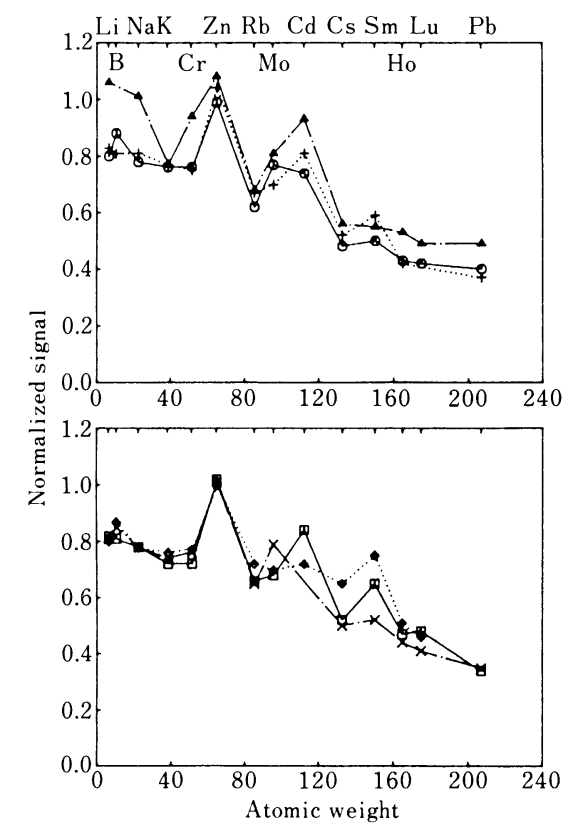

Analyte $\triangle: \mathrm{Al} \quad$ : : $\mathrm{Co}+: \mathrm{Y} \times:$ In $\square:$ La $\diamond: \mathrm{T}$

Analyte concentration $\mathrm{Al}: 5 \times 10^{6} \mathrm{M}$ Others : $1 \times 10^{-6} \mathrm{M}$ Matrix element $0.01 \mathrm{M}$

Fig. 7. Mass dependence of the matrix effect ${ }^{6)}$.

後市䝮され，妄く监及している。

\section{$3 \cdot 3$ ICP 質量分析}

ICP を発光分光分析用の光源としてではなく, 質量 分析計のイオン源として使用するという考えすは 10 年 ほど前にはじめて提条されたが,この方法は ICP 発光 分析に比べ足荲下限を2〜3けた低下させることがで き，また间位体比測起もでき间隹体希釈法の適用が川能 なので，构微星元絭の分星方法として人いに注目される ようになった。私どもも 1983 年から独自にこの装惪を 試作し，各種の特性を洞べ，特にマトリックス効果につ いて研究を行い，その原子里依住性を明らかにした。

Fig. 7 にその例をホす ${ }^{6)}$. 縦軸の值 1.0 はマトリックス 効果のないことをホす寸。マトリックス効果は複雑であっ て，極微星元兵のイオンとマトリックスのイオンの超宣 速膨非領域における衝突，イオン光学:系内での空閏電荷 の効果, プラズマ中でのイオン化斗衡のずれなどといっ た単一の機構では説明できず，おそらくいくつかの機構 が複令して起こっているものと考えられる.

ICP 啠荲分析は今後ますますの発展が期待できる力 法である。

\section{4. 極微量成分元素の分離濃縮の諸方法}

金属中の构微亩成分元絷をマトリックスから分離濃縮 するす法としては
( 1 ) 蒸発分離
( 2 ) 液液抽出分離
( 3 ) 選択溶解分離
(4) 沈殿分離
( 5 )電気化学的析出分離
( 6 ) 吸着分離
( 7 ) 带域融解

などの諸方法が用いられる7). 一般に気-液, 気一周, 液-液, 液一固など 2 相間に極微量成分元素とマトリックス元 素が異なった割命で分配される現象に基づくもので，足 量方法とは必対に各種の化学汶伈を利用したものが多 w.

これら諸方法の評価に当たっては次のような点を考虑 する必要がある。

(1)目的極微量成分元素の回収輩 $\left(R_{T}\right)$

$$
R_{T}=Q_{T} / Q_{T}{ }^{0} \times 100(\%)
$$

ここで $Q_{T}{ }^{0}$ と $Q_{T}$ はそれぞれ目的極微量成分元素の分 離前および分離後の質量である。ただし後者はコンタミ ネーションの補正をした值を用いる。これは放射性卜 レーサーを用いて簡単に測定できる.

( 2 )コンタミネーションの度令い

( 3 )濃縮係数 $(F)$

$$
F=\frac{Q_{T} / Q_{M}}{{Q_{T}^{0}}^{0} / Q_{M}{ }^{0}}=\frac{R_{T}}{R_{M}}
$$

ここで $Q_{M}{ }^{0}$ と $Q_{M}$ はそれぞれマトリックス元素の分離 前および分離後の質量, $R_{M}$ はマトリックス元素の回収 率である。

（4）簡易迅速性

( 5 ) 単元素濃縮か多元素间時濃縮か

(6)ふつうの分離操作かマイクロスケールの操作か これらのうち（3)〜 (6) は組み令わせる足量方法と関 連させて考えるべきものである.

以下私どもが開発した分離濃縮力法のいくつかについ て述べる.

\section{$4 \cdot 1$ 選択溶解分離}

金属試料を酸で分解したのち溶液を蒸発乾周すれば, 各種の極微量成分元素はマトリックス微絬昆(マトリッ クス元素の酸化物, 塩化物, 硫酸塩, 硝酸塩, 塩基性硝 酸塩など)の表面に濃緗される。これを塩酸, 硝酸, り ん酸などの無機酸, 水, エ夕ノール, アセトン, 1-ブ夕 ノールなどの有機溶媒, あるいはこれらの混令浴液の中 で超嗨波照射して，極微量成分元素をマトリックスのご く少量といっしょに浴出させる。このオ法によって，邀 当な条件を選べば，満足すべき回收辨とかなり高い濃維 係数で多元素同時濃絔ができる．たとえばビスマスを硝 酸に浴解してこれを蒸発乾周したのちさらに加熱する と, 各種塩基性硝酸ビスマス $\left(3 \mathrm{Bi}_{2} \mathrm{O}_{3} \cdot 3 \mathrm{~N}_{2} \mathrm{O}_{5} \cdot 2 \mathrm{H}_{2} \mathrm{O}\right.$, $\left.3 \mathrm{Bi}_{2} \mathrm{O}_{3} \cdot 3 \mathrm{~N}_{2} \mathrm{O}_{5} \cdot \mathrm{H}_{2} \mathrm{O}, 2 \mathrm{Bi}_{2} \mathrm{O}_{3} \cdot \mathrm{N}_{2} \mathrm{O}_{5}\right)$ を経て, 約 $450^{\circ} \mathrm{C}$ で酸化ビスマスに変化する。これに㮸って目的微量成分 


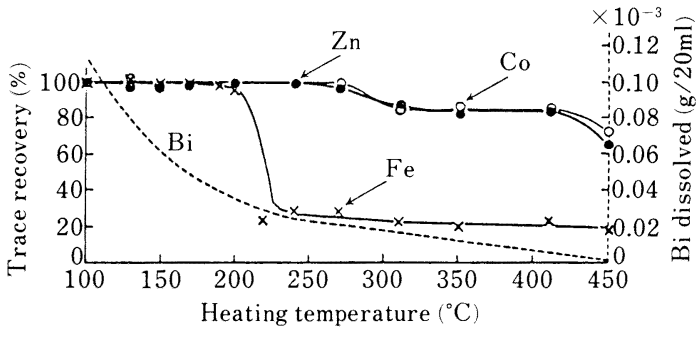

I g Bi : I $\mu \mathrm{g} \mathrm{Fe}, \mathrm{Co}, \mathrm{Zn}$

Fig. 8. Extraction of trace elements with $0.07 \mathrm{M}$ $\mathrm{H}_{3} \mathrm{PO}_{4}-0.12 \mathrm{M} \mathrm{HCl}(20 \mathrm{ml})$ from basic bismuth nitrate.

元素の回收率とマトリックス溶解度はFig. 8 のように

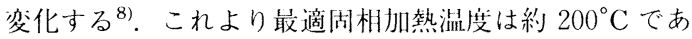
ることが分かる.

\section{$4 \cdot 2$ 電気化学的析出分離法}

マトリックス元素を溶液中に残し，目的極微量成分元 素だけを，グラシーカーボン電極に垃量的に電着させ， これをそのまま発光分光分析や巾性子枚射化分析の試料 として用いる.また水銀陰柯に构微量元素を電着析出さ せたのち水銀を蒸発除亡する方法もある。極微量の銀， 金，白金族元素などは，大量の銅，鉄，鐿などを含む溶 液から，外部電源を用いなくても，選択的かつ定量的に 水銀小滴またはエマルションによって捕集することがで きる。たとえば $50 \mathrm{ml}$ の溶液から超当波照射下で水銀工 マルション（径 1４ $4 \mathrm{~m} ） に$ に銀を迅速に捕集した例を Fig. 9 に示す ${ }^{9)}$. 硝酸溶液を用いる塨令には, 時間とと もに水銀が溶解し電位がしだいに崱になるので銀四收率 に跒大が牛ずる。銀捕集後，水銀エマルションは遠心分

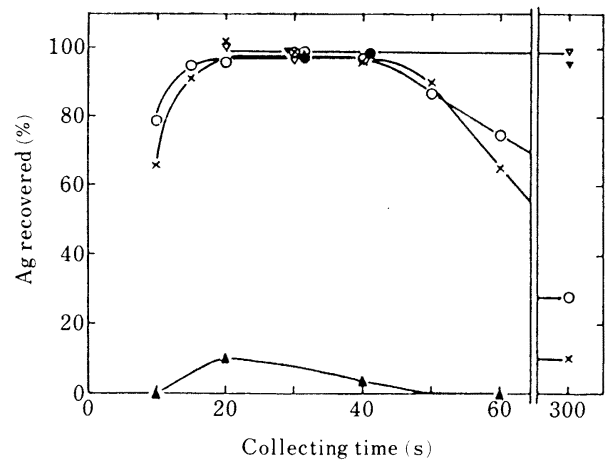

$\mathrm{Hg}$ in emulsion (mg) Sample solution

() : $150 \quad 0.2 \mathrm{M}$ nitric acid

- $150 \quad 0.2 \mathrm{M}$ nitric acid solution containing $\mathrm{lg}$ of $\mathrm{Pb}$

$\odot$ : $150 \quad 0.2 \mathrm{M}$ nitric acid solution containing $1 \mathrm{~g}$ of $\mathrm{Cu}$

$\times: 125 \quad 0.2 \mathrm{M}$ nitric acid

$\Delta: 20 \quad 0.2 \mathrm{M}$ nitric acid

$\nabla: 150$ Ammoniacal solution

$\boldsymbol{\nabla}: 150$ Ammoniacal solution containing $0.5 \mathrm{~g}$ of $\mathrm{Cu}$

Fig. 9. Collection of silver with mercury ${ }^{9)}$.

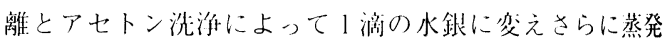
除上して，銀を策離することができる。このうj法によっ

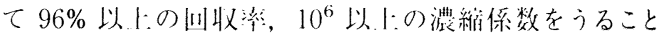
ができる.

\section{$4 \cdot 3$ 共沈浮選分離法}

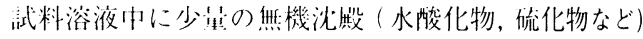
や们機沈殿(ジチゾン, 1-ニトロソ-2-ナフトール, $p$ ジメチルアミノベンジリデンローダニンなど）を生成さ

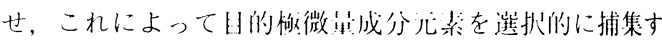
る其沈分離法では，たとえ捕集が足足的に进速に行われ ても，その後で沈殿を溶液から万過や遌心分離で分離す ることが林難で长时测を罗することが多い。私どもはこ

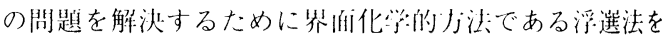

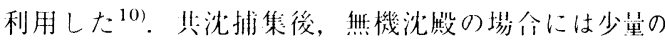
界面活性剤を加え，们機沈殿の培介にはそのまま，いず れも $1 \%$ 程度の，水とよく混ざる何機溶媒（メタノール， エタノール，アセトン，メチルセロソルブなど)の作在: 下で，たとえば Fig. 10 にふすような浮選セル中で浮選 を行う。等素または究父の送人によって非じた多数の小

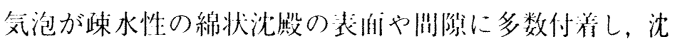
殿はすみやかに液垧にまで浮にし，泡沫猪によって支持 される。連統フローシステムを用い机ば其沈浮選法は 1001 の溶液にも適月できる。

\section{$4 \cdot 4$ 吸着分離法}

吸着体としてはイオン父換樹脂をはじめ, 多くの無機 存機物斦が用いられる。 Fig. 11 に陵イオン交換樹脂に よるタンタル中の銅の分離浱維の例を小す ${ }^{11}$. タンタ ルをふっ化水素酸と硄酸で加熱分解し、これを第イオン

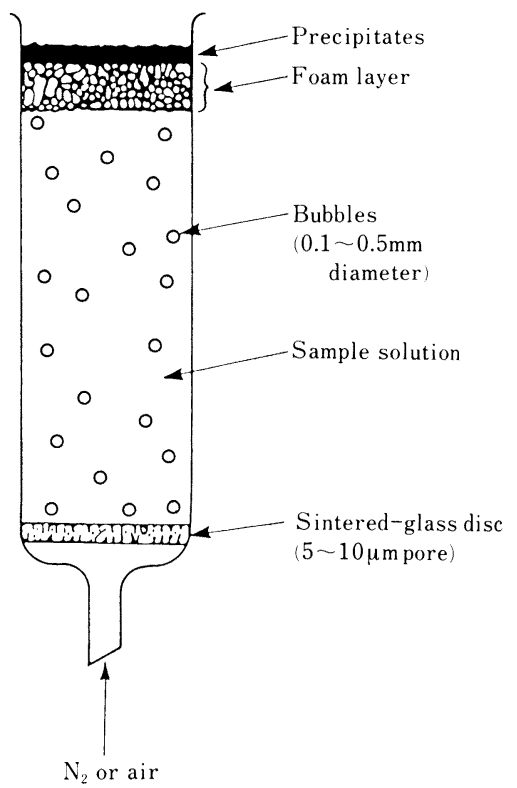

Fig. 10. Glass flotation cell. 


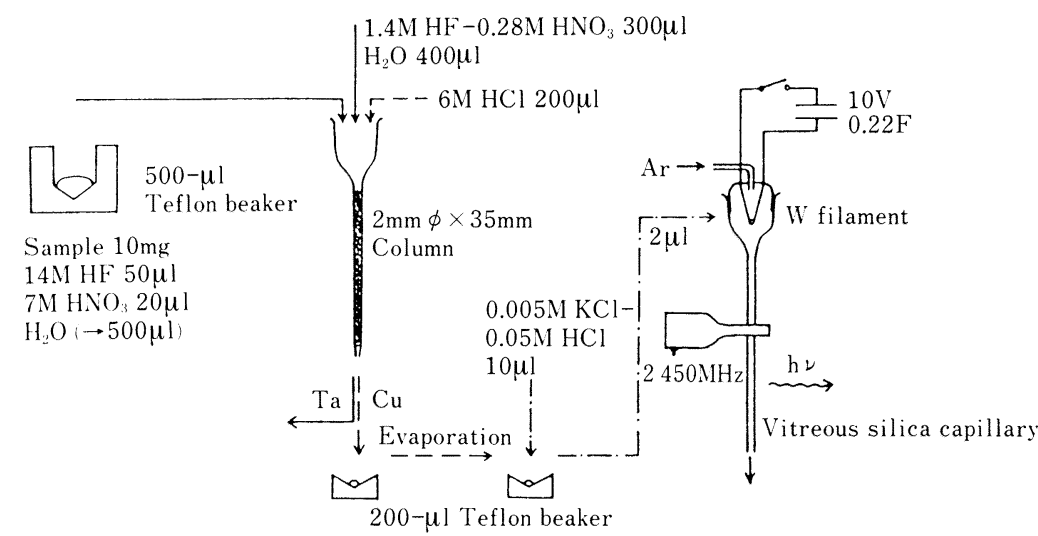

Dissolution Cation exchange MIP-OES

Fig. 11. Determination of $\mathrm{Cu}$ in high-purity tantalum powder.

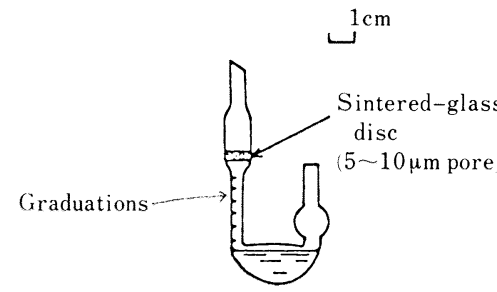

Decomposition, adsorption, etc.

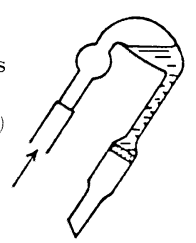

Filtration

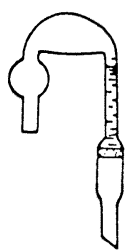

Measurement of solution volume

Fig. 12. Decomposition/separation vessel.

父換樹脂力ラムに通すと，剑は坣食に收着されるが，夕 ンタルはフルオロ錯䧔イオンとしてカラムを素通りす

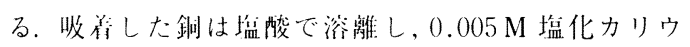
ム-0.05 M 酸溶液に変換したのち,タングステン・フィ

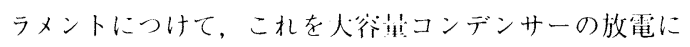

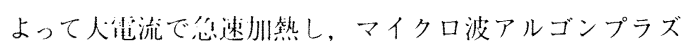

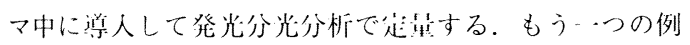
として鎑巾の銀のジチゾンによる吸看分離をあげよ $j^{12)}$.この)j法では试料 2 - 5 mg を硝酸に浴解し, 中 和後, 銀をジチゾン粉末 (径約 $5 \mu \mathrm{m}$ ) $0.5 \mathrm{mg}$ に選扒的 に吸着させる。これを硝酸とアセトンに溶解したのち黒

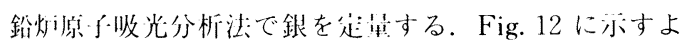
うに,たったつの無器で试料の分解, 吸看, 万過, 測 行などすべての分析操作をを行うため, 簡軣迅速で，また 極微星成分儿基の损火やコンタミネーションの拉それが 少ない.

以上一つの例では，いずれも $10 \mathrm{mg}$ 以下の试料を用

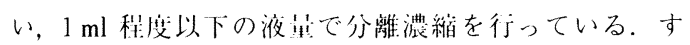
なわち $1 \mathrm{~g}$ 程度の倵と数十 $\mathrm{ml}$ 程度の液星を用いるふ
つうの操作に比べるとかなりマイクロ化されている。 イクロスケールの分離濃縮操作には次のような特长があ る.

(1)貴重試料の分析や局所分析に有用である.

(2)高価な高純度試薬が節約できる。

( 3 ) 廃液が少ない。

(4)分析操作に必要なスペースが少なくてすむ.

(5)しばしば迅速に行うことができる.

すでに述べたように，現在多くの場令ナノグラムからピ コグラムレベルの走量下限が得られるので, ミリグラム 量の試料採取量で, $\mu \mathrm{g} / \mathrm{g}$ 高 $\mathrm{ng} / \mathrm{g}$ レベルの極微量成分 元素の走量が叮能である. 多くの分析機器における試料 導入量はマイクロリッターレベルであるので, 分離濃縮 の操作をマイクロスケールで行うことは無䭾が少なく令 理的であろう.

\section{$4 \cdot 5$ コンタミネーションの防止対策}

いかに分離濃縮力法が, 回収率や濃縮係数などの点で すぐれていても，コンタミネーションが起こればこれは 金く無意味になる。コンタミネーションのうち，ふん讲 


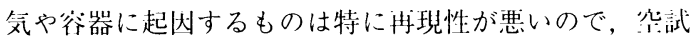
験などによってこれを正確に補正することははとんど不 叮能である. 従ってコンタミネーションを橔力減少させ ることが, 極微量成分元素の定量, とくに分離濃維を併 用する場令に重要になってくる.

ふん井気からのコンタミネーションを減少させるため には，いわゆるクリーンルームの使用が望ましい．しか し高清浄度のクリーンルームは建設, 保守に多額の費用 がかかるうえ，分析者にとっても使用しにくい，従って 清浄度はやや劣るクリーンルームの中で, クリーンフー

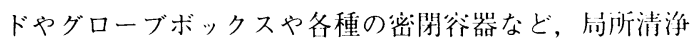
空閣や閉鎖系を圢みに活用するほうがより实際的であろ j.

容器材筫としては, 石英ガラス, テフロン, 白全, グ ラシーカーボンなどがあるが, 対化学薬品性, 耐熟性, 価格その他の点で理想的なものは存在しない, 表面処理 はコンタミネーション防止にきわめて有効で，たとえば 㚣価なパイレックスガラス $\left(81 \mathrm{SiO}_{2}-13 \mathrm{~B}_{2} \mathrm{O}_{3}-4 \mathrm{Na}_{2} \mathrm{O}-\right.$ $2 \mathrm{Al}_{2} \mathrm{O}_{3}$, 重量\%)でも，アルコキシドを用いる $78 \mathrm{SiO}_{2}-$ $21 \mathrm{ZrO}_{2}-1 \mathrm{Na}_{2} \mathrm{O}$ ( $\left.\mathrm{mol} \%\right)$ ガラス薄膜 (50 nm 厚) の生成に よって,ほう素やアルミニウムによるコンタミネーショ ンを(3)，また硝酸カリウムー硝酸カルシウム混合溶融塩 処理による表面層の改質によって，ナトリウムのコンタ ミネーションを(4) 防此することができた。

高純度試薬についても, 市販品は高琎でまた不十分な 純度のものも多いので, 分析者自らが精製する必要がし ばしばある。

\section{5.おわりに}

以上金属中の極微量成分元素の分離と足量についてお 話ししたが, 今後の問題としてつぎのようなことがある.

( 1 ) $\mathrm{ng} / \mathrm{g}$ 以下の極微量成分元素の定量に適するよう な新しい高感度, 高精度, 高選択性の機器分析力法の開 発. 最近 20 年間の進歩を媔みても, 新しい原理に基づ く方法が将来現れるであろうことは疑いのないところで ある。また機器分析においては原理は闹じでも機器の改 良によってその能力が著しく们上するので，この面でも 行うべきことが多々ある。
( 2 )損火やコンタミネーションが少なく, 簡単进速な

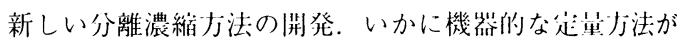
進歩しても，分離濃維が不必要になることはなさそうに 思われる。

(3)分離濃縮と分星を介理的に組み令わせること。こ のためには，‥つの研究グループで，化兴的な分離濃縮 技術の研究と分析機器の試作ならびにこれについての基

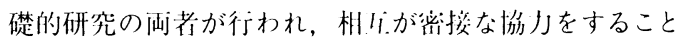
が大划であろう。

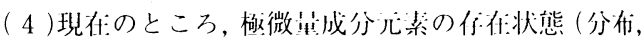
周溶，析出など）についての情郝をうることはむずかし いのでこの片晌の研究をする必要がある.

今後これらの方岶に扔いてますますの研究が期後され るゅえんである。

\section{文献}

1) 水池 教: 化学:と1: 栄, 36 (1983), p. 782

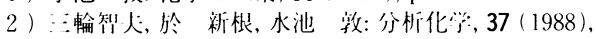
p. 128

3 ) H. Kawagienti, T. ITo, R. Silut: and A. Mizhike: Anal. Chem., 52 (1980), p. 2440

4 ) H. Kawagilicili, T. Tanaka, S. Muira, J. XU and $A$. Mizuike: Spectrochim. Acta, 38B (1983), p. 1319

5 ) $H$. Kawagichi, M. OKalı, T. IтO and A. Mizulke: Anal. Chim. Acta, 95 (1977), p. 145

6 ) $Y$. Kim, $H$. Kawagilchi, $T$. Tanaka and $A$. Mizuike: Spectrochim. Acta, 45B (1990)), p. 333

7 ) A. Mizuike: Enrichment Techniques for Inorganic Trace Analysis (1983) [Springer-Verlag, Berlin-Heidelberg New York ]

8 ) A. Mizuike and $K$. Fukuta: Mikrochim. Acta, 1972 (1972), p. 257

9 ) A. Mizuike, $K$. Fukuba and T. Sakamoto: Bull. Chem. Soc. Jpn., 46 (1973), p. 3596

10) A. Mizuike and M. Hirail):: Pure \& Appl. Chem., 54 (1982), p. 1555

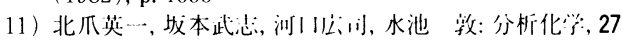
(1978), p. 566

12) A. Mizuike, M. Hiraille: and S. Kawakubo: Mikrochim. Acta, 1979 II (1979), p. 487

13) A. Mizuike and A. Iino: Anal. Chim. Acta, 111 (1979), p. 251

14) A. Mizuike and A. Iino: Anal. Chim. Acta, 124 (1981), p. 427 